\title{
Toxicity Bio-Monitoring of Shkodra Lake Surface Water Using a Higher Plant Assay
}

\author{
Prof. Ass. Dr. Anila Mesi (Dizdari) \\ University of Shkodra Luigj Gurakuqi, Faculty of Natural Sciences, \\ Department of Biology and Chemistry, Shkodër, Albania \\ aniladizdariyahoo.it \\ Dr. Ditika Kopliku \\ University of Shkodra Luigj Gurakuqi, Faculty of Natural Sciences, \\ Department of Biology and Chemistry, Shkodër, Albania \\ ditikad@yahoo.com
}

\section{Doi:10.5901/ajis.2013.v2n8p133}

\section{Abstract}

Health and quality of biota in natural ecosystems are directly affected by different kind of pollutants, accumulated because of uncontrolled releases into the environment of industrial effluents and urban waste, as well as by drainage, flooding, intensive farming and tourism. Bio-monitoring of Shkodra Lake water quality was done using Allium cepa L. assay. Bulbs were grown on surface water samples collected from six stations: S1-S3 at east and S4-S6 at west lake waterside, during August 2010-2013. The reaction of root meristematic tissue and its genetic material to the presence and quantity of potential cyto and genotoxic chemicals was done by evaluating macro and microscopic parameters, as: root length, mitotic and phase indexes, interphase nuclear volume, chromosome abnormalities frequency and types. The most toxic samples resulted 2011 and 2013 and the east waterside ones, which could be due to massive flooding during the respective years and the different trophy level between east and west lake basin sides. There were detected slight traces of toxic and persistent water chemical pollutants, serving as an alert of their possible bioaccumulation and negative impact on biota and human health. The A. cepa test could be successfully applied as a simple, short-term and inexpensive approach for environmental quality evaluation in developing areas and countries such as Shkodra region and Albania.

Keywords: bio-monitoring, Shkodra Lake, chemical pollutants, Allium cepa assay, cytotoxicity, genotoxicity

\section{Introduction}

Health and quality of biota in natural ecosystems are directly affected by different kind of pollutants, accumulated because of uncontrolled releases into the environment of industrial effluents, urban waste, as well as by drainage, flooding, intensive farming and tourism (Albering et al., 1999). Water has always been considered a renewable natural resource. However its consumption and pollution degree have been tremendously increased during the last decades by local and global acceleration of urbanization and industrialization processes (Vargas, 2001).

Shkodra region (North-West Albania) is distinguished for a unique and complicated water system, hydrologically and ecologically interdependent, which includes: Shkodra Lake (a transboundary lake with Montenegro), Buna and Drini Rivers and many streams. Shkodra Lake $\left(40^{\circ} 10^{\prime} \mathrm{N}, 19^{\circ} 15^{\prime} \mathrm{E}\right)$ is the largest lake in the Balkan Peninsula, fluctuating seasonally from 370 to $600 \mathrm{~km}^{2}$. Approximately one third of the lake $\left(142 \mathrm{~km}^{2}\right)$ is situated in Albania. The lake has one outlet - Buna River and some inlets, the biggest of which is Moraca River (Montenegro). The lake is located on a karstic terrain, while many small islands and cryptodepressions (containing sublacustrine springs), are localized surrounding lake shores (Dhora, 2012).

Shkodra Lake represents one of the most diverse and interesting ecological areas of South-East Europe. The Albanian part of the lake and Buna River were included in the Ramsar List of Wetlands with a global importance in 2006 (Ramsar, 2010). The lake is a subtropical (mean temperature value of $14.9^{\circ} \mathrm{C}$ ) and shallow (mean water depth of $5.01 \mathrm{~m}$ ) water body, having a conductivity of 100-343 $\mu \mathrm{S} \mathrm{cm}^{-2}$, a mean altitude $<50 \mathrm{~m}$, high dissolved-oxygen content (7-12 mg/l in surface waters) and pH values differing from 7.2 to 8.3 (Neziri et al., 2009; Bushati et al., 2012, Malollari et al., 2012). The south and south-western watersides of the lake are structured mostly by calcareous (limestone) rocks, serving for recreative and touristic activities. Meanwhile northern and north-eastern watersides are plain and siltstone, providing an 
extensive semi-littoral zone used as agricultural field. Spring and autumn rainfall floods the northern banks, greatly increasing the range of habitats for lake biota and providing extensive spawning and feeding areas for fish and birds. Additionally on the basis of bathymetric values the catchment area of the lake on Albanian part can be divided into 2 basins, west and east basin. The ecological status of the lake can be actually classified as good to moderate. Some values of biological quality elements of the lake such as: decrease of populations of consumed species (Acipenser sturio, Cyprinus carpio and Alburnus alburnus), presence of invasive plant species (Amorpha fruticosa) and aggressive introduced fish species (Percidae) deviate moderately from normal type of undisturbed conditions as a result of human activity (Dhora, 2012; Rakaj, 2012).

The assessment of water quality is closely related to the application of monitoring and remediation projects which aim to reduce the risk that aquatic ecosystems incur by hazardous substances, even when they are present in low concentrations (Smaka-Kincl et al., 1996; Vargas et al., 2001). The integrated monitoring is reserved for coordinated monitoring activities comprising chemical and biological measurements in a variety of environmental media (Dick de Zwart, 1995; Smaka-Kincl et al., 1996; Žhegura et al., 2009). Plant-based bioassays have recently gained notable recognition among the eco-toxicological tools for the water quality assessment, due to their comparative simplicity, sensitivity, low cost and good correlation to other toxicity bio-tests (Žhegura et al., 2009; Siddiqui \& Ahmad, 2011). Providing a biological early warning system in toxicity monitoring procedures, the Allium cepa L. test have been widely used for the detection of phyto and genotoxic effects of potentially polluting substances present in fresh waters (Fiskesjö, 1988; Smaka-Kincl et al., 1996; Matsumoto et al., 2006; Leme \& Marin-Morales, 2009; Düsman et al., 2012; Mesi \& Kopliku, 2011; Kopliku et al., 2012; Kopliku \& Mesi, 2013; Mesi et al., 2013).

The purpose of the present investigation was the bio-monitoring of Shkodra Lake water quality by using A. cepa assay.

\section{Methods}

\subsection{Sampling collection}

Sampling was done during August 2010, 2011, 2012 and 2013 at east and west watersides of Shkodra Lake (Fig. 1). The toxicity/genotoxicity testing of natural waters as lakes and rivers has established that the samples collected during summer are the most toxic, probably due to greater water evaporation, thereby resulting in the concentration increase of toxicants. Surface water samples were collected from Shegan $\left(S_{1}\right)$, Dobër $\left(S_{2}\right)$, Vrakë $\left(S_{3}\right)$, Zogaj $\left(S_{4}\right)$, Shirokë $\left(S_{5}\right)$, and Buna Bridge $\left(\mathrm{S}_{6}\right)$. Water samples were preserved in polyethylene bottles washed with $5 \%$ hydrochloric acid and rinsed out with abundant distilled water in the laboratory and abundant lake water immediately before collection. The labeled bottles with samples were transferred to the laboratory and stored in refrigerator in $2-4^{\circ} \mathrm{C}$. Their toxicity screening was performed within $48 \mathrm{~h}$ from collection. Filtered tap water was used as negative control sample.

\subsection{Biological material}

Healthy and equal-sized bulbs ( $\varnothing \approx 1.5-2 \mathrm{~cm}$ ) of common onion (Allium cepa L., native ecotype Drishti), not previously treated with plant growth regulators, were obtained from Shkodra region markets. The plant material was stored under dry conditions at $+10-20^{\circ} \mathrm{C}$ for one year and than bulbs, which were dry, moldy or had started shooting green leaves were discarded.

\subsection{Test procedure}

The yellow-brownish outer scales of onion bulbs have been removed carefully, leaving the ring of root primordia intact. The bulbs were grown and observed for 72 hours in the laboratory. All experiments for growth inhibition, cytotoxicity and genotoxicity tests were set up in a completely randomized design with twelve test tubes and three replicates per sample. Each series has been filled with respective water samples. On top of each test tube one onion bulb has been put with the root primordia downward in the liquid. The test procedure was performed in room temperature (at about $+20^{\circ} \mathrm{C}$ ), with a natural light-dark regime and protected from direct sun light.

Macro and microscopic endpoints as: root length (MRL), mitotic and phase indexes (MI and PI), interphase nuclear volume (INV) and chromosomal aberration frequency (FAC) and types (CA) in root meristematic tissue were used to determine the phytotoxic and genotoxic effects of Shkodra Lake water samples. 


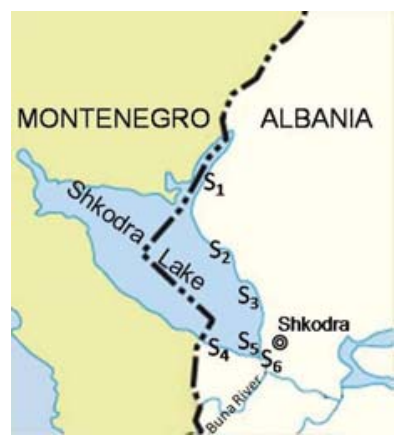

Fig. 1. Map of sampling points in Shkodra Lake

The microscopic investigations were done after $48 \mathrm{~h}$ under an optic microscope Leitz-Diaplan using a 500x oil-immersion lens. From each of 5 bulbs randomly chosen in each champion of samples, one root tip $(10 \mathrm{~mm})$ was taken. The roots were placed on slides and the terminal root tips $(1-2 \mathrm{~mm})$ were cut off and used for further preparation. Slides were prepared in accordance with the standard procedure for orcein staining of squashed material. The number of dividing cells (NDC) was determined in 1000 examined cells in the field of view, than mitotic index was scored as percent ratio of NDC per 1000 cells. PI values of prophase, metaphase and ana/telophase have been scored as percentage of MI. For the examination of INV, it was obtained the mean of two diameters of each selected orcein-stained nucleus, observed at right angles to each-other and measured under oil-immersion objectives. INV was evaluated using the formula $4 / 3 \pi r^{3}$, where $r$ is the radius of the nuclei. Means of MI, PI and INV values of 5 slides per sample have been calculated. 1500 dividing cells ( 300 cells per each of 5 slides per sample) have been observed for the characterization and classification of chromosome aberrations (CA). The frequencies of aberrant cells (FAC) and CA types were expressed as percent ratio. Macroscopic investigations including morphology and length of roots were done after $72 \mathrm{~h}$. A mean root length (MRL) of each series per sample was calculated.

\subsection{Statistical analysis}

Analysis of Variance (One-way ANOVA) and post-hoc Student Newman-Keuls (SNK) tests were used to test for significant differences of all evaluated parameters. All the results were expressed as the mean of three replicates per sample \pm standard deviation (SD). Parameter differences against corresponding negative control were considered statistically significant at level $5 \%$.

\section{Results and discussion}

The present study was carried out to bio-monitor east and westside water quality of Shkodra Lake by using A. cepa assay. Tables 1 and 2 represented all data about the morphological and cyto-genetic analyzes of $A$. cepa roots exposed to different lake water samples.

\subsection{Macroscopic toxicity evaluation}

Root elongation and morphology are important parameters for the evaluation of plant growth under water toxicity. Root growth reduction over 55\% strongly indicates the presence of phytotoxic substances (Fiskesjö, 1988). The morphology of A. cepa roots exposed to tap water for $72 \mathrm{~h}$ (negative control) was normal during four years monitoring period (20102013). Root length values of these samples $(3.74-4.52 \mathrm{~cm}$ ) showed a linear growth, approximately $1-1.5 \mathrm{~cm} /$ day, which means good chemical quality of tap water taken from the water supply network of Shkodra city (Fiskesjö, 1988). The water samples $S_{2}, S_{3}, S_{5}$ and $S_{6}$ induced limited morphological abnormalities such as: root bending $\left(S_{2}, S_{3}\right.$ and $\left.S_{6}\right)$ and sporadic stunted roots $\left(\mathrm{S}_{5}\right.$ and $\mathrm{S}_{6}$ ), especially during 2011 and 2013. Over four years bio-monitoring showed a significant root length decrease of 18-25\% compared to the respective NC-S ( $p<0.05$ using SNK test) and the range resulted 2011 $\left(S_{3}, S_{2}, S_{6}, S_{1}\right)>2013\left(S_{3}, S_{1}, S_{2}\right)>2012\left(S_{3}\right)>2010\left(S_{3}\right)$. All eastside samples $\left(S_{1}, S_{2}, S_{3}\right)$ demonstrated slightly higher 
phytotoxic effect than westside ones, especially during 2011 and 2013, while $S_{3}$ sample resulted persistent during the whole bio-monitoring period (Tab. 1 and Fig. 2a).

\subsection{Microscopic toxicity evaluation}

\subsubsection{Cytotoxic effects}

The mitotic index is a microscopic endpoint which reflects cell division and proliferation activity of meristematic tissue. It is considered an important parameter when evaluating the rate of plant root growth, being frequently reported in the literature. MI has been closely correlated to the root length in the A. cepa (Smaka-Kincl et al., 1996; Kopliku et al., 2012). Meanwhile quantifying the reduction of cell division in root meristematic cells serves to quickly determine the presence of toxic substances in the environment and for the monitoring of pollution levels in natural environments (Matsumoto et al., 2006). As shown in Table 1 and Figure 2b, significant inhibition of cell division in onion roots over the four years period were detected in water samples: $S_{3}$ (21-29\%: 2010-2013), S (23-26\%: 2010-2013), S2 (23-24\%: 2011-2013), S4 (2022\%: 2011-2013), S 6 (15-18\%: 2010, 2012 and 2013), S5 (12-14\%: 2011-2013) compared to the respective NC-s (p<0.05 using SNK test). This fact indicated that the examined water samples contain substances that may be toxic, inhibiting consequently cell division of $A$. cepa root cells. According to this parameter stronger mito-depressive effect was induced once more by 2011 eastside water samples, with $\mathrm{S}_{3}$ the most persistently cytotoxic one. The differences of diving cells number to corresponding NC showed in general the same significance as MRL values, fitting well with the above mentioned effects on onion root length. Mitotic index could be positively correlated to root length, proving that inhibition of root growth resulted from inhibition of cell division. Root growth inhibition due to water pollutants could be due to inhibition of root cell division/root elongation or to the extension of cell cycle. As shown in Table 1, the characterization of phase index in $A$. cepa cells exposed to tap water and $S_{2}, S_{4}$ and $S_{5}$ natural samples did not demonstrate any periodic irregularity of dividing cell cycles. Meanwhile the other lake samples $\left(S_{1}, S_{3}\right.$ and $\left.S_{6}\right)$ caused significant changes in prophase and metaphase stages, compared to corresponding NC-s ( $P<0.05$, using ANOVA test). Additionaly it was noted a certain tendency of metaphase decrease and prophase increase in all water samples and periodic assesments. These results demonstrated a slight obstruction of metaphase stage, and probably an inhibition of mitosis or extension of cell cycles, which could be attributed to the blocking of cell division at the end of the prophase by potentially present water contaminants. This might be as well the reason of Ml reduction observed in A. cepa roots grown in lake water. The evaluation of interphase nuclear volume (Tab. 1 and Fig. 2c) did not show significant reduction of nuclei size (2-13\%) in onion root cells exposed to tap water and lake samples, except 2013 S $_{3}(19 \%)$ and 2011 S6 (15\%). compared to corresponding NC-S ( $P<0.05$ using ANOVA test). Recorded INV reduction of onion cells may be attributed to the mitodepressive action of pollutants, by blocking the $\mathrm{G}_{1}$ stage and suppressing DNA synthesis.

\subsubsection{Genotoxic effects}

Root meristematic tissue is presumed as a suitable tool for screening mutagenic effect and potency of water pollutants and the suppression of its mitotic activity is usually accompanied by an increase of chromosome aberrations (Power \& Boumphrey, 2004). The cytogenetic analysis of this study revealed the potential presence of genotoxic and clastogenic compounds in the analyzed lake samples (Table $1 \& 2$ ). It was observed a positive correlation between growth inhibition and frequency of anomalous cells with chromosome aberrations in $A$. cepa roots: samples which did not induce phyto and cytotoxic effects did not show either genotoxic effects (NC-s and 2010-S 4 ), having FAC from 1.8-2.9\% (not significant at $P<0.05$, using ANOVA test); meanwhile all the other periodic water samples, where $A$. cepa roots incurred inhibition of growth and reduction of mitotic activity, simultaneously pointed out their genotoxic potency, inducing FAC higher than $3 \%$ up to $10.7 \%$ (significant at $P<0.05$ and 0.001 , using ANOVA test). Anyway it was noticed a sample exception where cytotoxicity was not strictly correlated to the genotoxicity. Not distinctly evidenced mito-depresive effect of $\mathrm{S}_{6}$ sample (the closest to Shkodra city) might be due to a transitory stimulating effects of nitrate, nitrite, ammonium and phosphate on the proliferation of $A$. cepa root-tip cells, because of the discharge of municipal sewage and tourism wastes. These wastes may have caused on the contrary the highest levels of genotoxicity observed during whole periodic assessment, compared to other samples (Fig. 2d). The most observed chromosome aberration types were due to chromatin dysfunction (stickiness, bridges and fragments) or spindle failure (c-mitosis)., while sporadic vagrant and ring chromosomes were observed in $\mathrm{S}_{1}, \mathrm{~S}_{2}, \mathrm{~S}_{3}, \mathrm{~S}_{5}$ and $\mathrm{S}_{6}$ samples. At $\mathrm{S}_{4}$ sample it was observed, in the cytoplasm of a few cells the development of two extended hyaline structures generating from the nucleus material, being a typical 
abnormality caused by Aluminium metal solution (Fiskesjo, 1988). There are no chemical data about Al concentration and pollution in Shkodra Lake, but it is a known fact the discharge of chemical pollutants from Aluminium Company (KAP) to Moraca River (Montenegro), the main tributary of the lake.

The evaluation of contamination degree in aquatic environments should not be based only on its physical and chemical characterization but it should be combined with biological assays (Žegura et al., 2009). Bio-assays can assess the potential toxic effects from all the water components (including those due to unknown substances and their synergic, antagonistic or additive effects) and allow an integrated evaluation of the impact in populations and communities (Power \& Boumphrey, 2004). The over four years water quality bio-monitoring of Shkodra Lake water by using a sensitive higher plant bioassay as $A$. cepa revealed that the most polluted samples resulted the 2011 and 2013 ones, which might be due to those years massive flooding (especially in $S_{3}, S_{2}, S_{1}$ and $S_{6}$ samples-representing the most damaged lake surrounding areas) and the continuous discharge of untreated wastes and chemicals from industrial, agriculture, municipal and tourism activities in Albanian and Montenegrin parts of lake. The water quality of Shkodra Lake is highlydependent from the typology of its catchment area. As a lowland lake, it is subject of natural eutrophication processes. Meanwhile on the catchment area of Albanian part there is not any hazardous industrial pollution source to influence on the characteristics of the lake water. Chemicals used in agriculture activities (fertilizer and pesticide residues) on the east side of the lake and municipal wastes are the main causes probably affecting the quality of water. The trophic state of this lake is considered as oligotrophic. On the other hand this lake is described as a bicarbonate one (due to karstic characteristics of basin), which make it a favorable aquatic environment for the development of flora and fauna (Dhora, 2012; Rakaj, 2012). Based on bathymetric values the west basin is short and rocky and the lake on this side is deep. The east basin is wider and has gradual depth. Serving as an agricultural field, this part of the lake is the most ecologically sensible and economically important one. Lots of incoming waters are situated in this part (Rrjolli and Banushi streams, Vraka runnel and more than 46 wellsprings), which bring into the lake different materials because of the erosion and human activities. Most of the field on this side is private property with farming activity. That's why actually it is difficult to control the agrochemicals usage, which has caused higher values of nutrients (especially phosphate ions) at this side of the lake, compared to westside one (Malollari et al., 2012).

The results of the present investigation could make evident the fact that the eastside of the lake is actually the most persistently polluted during whole bio-monitoring period, because its samples could induce higher mitotic activity and chromosomal damages and alterations in morphological parameters of $A$. cepa roots, compared to westside ones and tap water. This study fulfilled some related examinations made in former studies (Mesi, \& Kopliku, 2011; Kopliku et al., 2012), being also in agreement with results of physical-chemical and biological analyzes of the same waters (Neziri et al., 2009; Bushati et al., 2012; Malollari et al., 2012; Rakaj, 2012.). The highest phyto/cyto and genotoxic effect of S6 sample could be attributed to the fact that Vraka runnel crosses whole Malësia e Madhe lowland and flows into the lake, abundantly releasing solid and liquid wastes (domestic and agricultural) especially during winter and spring time, concentrated after the evaporation 2010-2013 hot summers. S sample appeared to be a physiologically and genetically damaging water sample, as evidenced by its capacity to induce significant growth inhibition and chromosome damages, as well. This might be a consequence of: pesticide residues used in the surround area, geografic position and structure (a lake bay) or a considerable unknown industrial chemical residue deposited some years ago in the railway station, closed to Shegan waterside. Root growth in plants is a metabolically active stage, quite sensitive to the environmental stimuli (Siddiqui \& Ahmad, 2011). Our observation resulted consistent to this fact in terms of inhibition in root growth, reduction of mitotic activity and mutagenicity inducement, caused by potentially present toxicants in the examined water samples of the lake. Additionally this study revealed that the periodic and seasonal changement of clima conditions (temperature, precipitations, etc.) can influence composition and biodegradation level of water pollution and consequently its toxic impact.

\section{Conclusions}

The over four years results in the present study indicated slight toxicity of the examined Shkodra Lake samples, mostly in eastside basin, serving as an alert of pollutants presence, even in low concentrations. A. cepa bioassay exhibited different sensitivities, showing some kind of correlation to lake water quality through the physical-chemical parameters of catchment area and their periodic alterations. The present screening provided additional information about the mutagenicity of mixed and unknown pollutants potentially present in lake surface waters, by demonstrating their potency to induce macroscopic, cyto and genotoxic effects in A. cepa roots. This investigation showed that macroscopic and cytogenetic techniques, combined with physical-chemical and sapro-biological analysis, can better screen qualitatively, 
quantitatively and periodically the toxicity of water pollutants and their direct influence on the biota of Shkodra Lake and its surrounding ecosystems, which in turn may indirectly affects human health.

Table 1. Periodic effects of Shkodra Lake water samples on length, mitotic and phase indexes, interphase nuclear volume and frequency of anomalous cells with chromosome aberrations in A. cepa roots during 2010-2011

\begin{tabular}{|c|c|c|c|c|c|c|c|c|}
\hline \multirow{2}{*}{$\begin{array}{c}\text { Periodic } \\
\text { water sampling }\end{array}$} & \multirow{2}{*}{ Samples } & \multirow{2}{*}{$\begin{array}{l}\mathrm{MRL} \pm \mathrm{SD} \\
(\mathrm{cm})\end{array}$} & \multirow{2}{*}{$\begin{array}{c}\mathrm{Ml} \pm \mathrm{SD} \\
(\%)\end{array}$} & \multicolumn{3}{|c|}{$\mathrm{PI}(\%)$} & \multirow{2}{*}{$\begin{array}{c}\text { INV } \pm \text { SD } \\
\left(\mu \mathrm{m}^{3}\right)\end{array}$} & \multirow{2}{*}{$\begin{array}{c}\mathrm{FAC} \pm \mathrm{SD} \\
(\%)\end{array}$} \\
\hline & & & & $\mathrm{Pr}$ & $\mathrm{Mt}$ & $\mathrm{A} / \mathrm{T}$ & & \\
\hline \multirow{7}{*}{2010} & $\mathrm{NC}$ & $3.74 \pm 0.52^{\mathrm{a}}$ & $13.98 \pm 1.65^{a}$ & 21.06 & 37.92 & 41.02 & $496.63 \pm 0.82$ & $1.8 \pm 0.53$ \\
\hline & $\mathrm{S}_{1}$ & $3.07 \pm 0.34^{a b}$ & $10.76 \pm 0.49 b$ & 22.71 & 34.59 & 42.70 & $466.83 \pm 0.57$ & $5.8 \pm 0.31 *$ \\
\hline & $\mathrm{S}_{2}$ & $3.22 \pm 0.17 \mathrm{a}$ & $11.60 \pm 0.89 \mathrm{ab}$ & 23.11 & 35.67 & 41.22 & $461.87 \pm 0.83$ & $4.9 \pm 0.29 *$ \\
\hline & $\mathrm{S}_{3}$ & $2.99 \pm 0.11^{b}$ & $11.04 \pm 0.23^{b}$ & 23.47 & $32.08^{*}$ & 44.45 & $451.93 \pm 0.33$ & $7.6 \pm 0.12^{\star \star}$ \\
\hline & $\mathrm{S}_{4}$ & $3.48 \pm 0.20^{a}$ & $12.86 \pm 0.94^{a}$ & 20.90 & 36.46 & 42.64 & $486.70 \pm 0.48$ & $2.9 \pm 0.56$ \\
\hline & $\mathrm{S}_{5}$ & $3.59 \pm 0.13^{a}$ & $12.58 \pm 0.77^{a}$ & 19.89 & 38.18 & 41.93 & $506.56 \pm 0.27$ & $3.6 \pm 0.22^{*}$ \\
\hline & $\mathrm{S}_{6}$ & $3.18 \pm 0.27 \mathrm{ab}$ & $11.88 \pm 0.95^{\mathrm{ab}}$ & $25.31^{*}$ & $30.65^{*}$ & 44.04 & $442.01 \pm 0.15$ & $7.7 \pm 0.61^{\star *}$ \\
\hline \multirow{7}{*}{2011} & $\mathrm{NC}$ & $4.22 \pm 0.65^{a}$ & $14.02 \pm 0.61^{a}$ & 20.33 & 35.55 & 44.12 & $587.72 \pm 0.97$ & $2.2 \pm 0.74$ \\
\hline & $\mathrm{S}_{1}$ & $3.42 \pm 0.09^{b}$ & $10.38 \pm 0.29 \mathrm{~cd}$ & 23.25 & $30.14^{*}$ & 46.61 & $540.70 \pm 0.41$ & $6.8 \pm 0.43^{* *}$ \\
\hline & $\mathrm{S}_{2}$ & $3.29 \pm 0.24^{b c}$ & $10.79 \pm 0.24^{\mathrm{cd}}$ & 19.58 & 32.98 & 47.44 & $528.95 \pm 0.83$ & $5.4 \pm 0.38^{*}$ \\
\hline & $\mathrm{S}_{3}$ & $3.17 \pm 0.14^{c}$ & $9.95 \pm 0.53^{d}$ & $27.03^{*}$ & $29.67^{*}$ & 43.30 & $511.32 \pm 0.55$ & $9.1 \pm 0.68^{\star *}$ \\
\hline & $\mathrm{S}_{4}$ & $3.59 \pm 0.11^{\mathrm{ab}}$ & $10.94 \pm 0.27^{c}$ & 20.53 & 36.49 & 42.98 & $552.46 \pm 0.61$ & $3.1 \pm 0.56^{*}$ \\
\hline & $\mathrm{S}_{5}$ & $3.80 \pm 0.27^{a}$ & $12.34 \pm 0.65^{b}$ & 22.74 & 33.53 & 43.73 & $552.08 \pm 0.42$ & $4.4 \pm 0.32^{\star}$ \\
\hline & $\mathrm{S}_{6}$ & $3.38 \pm 0.18^{b}$ & $12.48 \pm 0.18^{b}$ & $25.87^{*}$ & $28.19^{*}$ & 45.94 & $499.56 \pm 0.21$ & $10.7 \pm 0.22^{\star *}$ \\
\hline
\end{tabular}

Notes: Means with different superscript letter along the column are significantly different $(p<0.05)$ in the SNK test, while means with asterisks are significantly different from control: ${ }^{*} P<0.05$, ${ }^{* *} P<0.001$ according to One-way ANOVA test; NCnegative control (tap water); $\mathrm{S}_{1}$ - $\mathrm{S}_{6}$-lake water samples: $\mathrm{S}_{1}$-Shegan, $\mathrm{S}_{2}$-Dobër, $\mathrm{S}_{3}$-Vrakë, $\mathrm{S}_{4}$-Zogaj, $\mathrm{S}_{5}$-Shirokë, $\mathrm{S}_{6}$-Buna Bridge; MRL-mean root length; MI-mitotic index, PI-phase index; Pr-Prophase; Mt-Metaphase; A/T-Ana/Telophase; INVinterphase nuclear volume; FAC-frequency of aberrant cells; SD-standard deviation.

Table 2. Periodic effects of Shkodra Lake water samples on length, mitotic and phase indexes, interphase nuclear volume and frequency of anomalous cells with chromosome aberrations in A. cepa roots during 2012-2013

\begin{tabular}{|c|c|c|c|c|c|c|c|c|}
\hline \multirow{2}{*}{$\begin{array}{c}\text { Periodic } \\
\text { water sampling }\end{array}$} & \multirow{2}{*}{ Samples } & \multirow{2}{*}{$\begin{array}{c}\mathrm{MRL} \pm \mathrm{SD} \\
(\mathrm{cm}) \\
\end{array}$} & \multirow{2}{*}{$\begin{array}{c}\mathrm{Ml} \pm \mathrm{SD} \\
(\%)\end{array}$} & \multicolumn{3}{|c|}{$\mathrm{PI}(\%)$} & \multirow{2}{*}{$\begin{array}{c}\text { INV } \pm \text { SD } \\
\left(\mu \mathrm{m}^{3}\right)\end{array}$} & \multirow{2}{*}{$\begin{array}{c}\mathrm{FAC} \pm \mathrm{SD} \\
(\%)\end{array}$} \\
\hline & & & & $\mathrm{Pr}$ & $\mathrm{Mt}$ & $\mathrm{A} / \mathrm{T}$ & & \\
\hline \multirow{7}{*}{2012} & NC & $4.52 \pm 0.55$ & $14.43 \pm 1.28$ & 22.19 & 33.96 & 43.85 & $523.34 \pm 0.79$ & $2.6 \pm 0.45$ \\
\hline & $\mathrm{S}_{1}$ & $3.75 \pm 0.23^{a b}$ & $11.40 \pm 0.39 b c$ & 20.91 & 32.12 & 46.94 & $471.03 \pm 0.88$ & $6.5 \pm 0.36^{\star *}$ \\
\hline & $\mathrm{S}_{2}$ & $3.66 \pm 0.36^{\mathrm{ab}}$ & $11.69 \pm 0.16^{b c}$ & 21.88 & 35.15 & 42.97 & $481.47 \pm 0.70$ & $4.8 \pm 0.24^{*}$ \\
\hline & $\mathrm{S}_{3}$ & $3.53 \pm 0.12^{b}$ & $10.97 \pm 0.22^{c}$ & 24.18 & $29.39 *$ & 46.43 & $460.54 \pm 0.35$ & $8.3 \pm 0.19 * *$ \\
\hline & $\mathrm{S}_{4}$ & $4.07 \pm 0.39^{a}$ & $12.27 \pm 0.94^{a b}$ & 23.52 & 31.26 & 45.22 & $497.17 \pm 0.15$ & $3.2 \pm 0.25^{\star}$ \\
\hline & $\mathrm{S}_{5}$ & $4.25 \pm 0.43^{a}$ & $12.84 \pm 0.77^{a}$ & 25.07 & 34.00 & 40.93 & $507.64 \pm 0.48$ & $4.1 \pm 0.51^{*}$ \\
\hline & $\mathrm{S}_{6}$ & $3.78 \pm 0.27^{\mathrm{ab}}$ & $11.83 \pm 0.25^{b}$ & $30.05^{*}$ & $28.64^{*}$ & 41.31 & $465.77 \pm 0.44$ & $8.9 \pm 0.87^{\star *}$ \\
\hline \multirow{7}{*}{2013} & $\mathrm{NC}$ & $3.97 \pm 0.57^{a}$ & $13.67 \pm 1.06^{a}$ & 21.03 & 36.16 & 42.81 & $558.66 \pm 0.61$ & $2.1 \pm 0.78$ \\
\hline & $\mathrm{S}_{1}$ & $3.22 \pm 0.10^{b c}$ & $10.39 \pm 0.25^{c}$ & 22.61 & 33.83 & 43.56 & $502.79 \pm 0.12$ & $6.2 \pm 0.18^{\star *}$ \\
\hline & $\mathrm{S}_{2}$ & $3.26 \pm 0.07^{b}$ & $10.35 \pm 0.19 c$ & 20.47 & 34.70 & 44.83 & $487.03 \pm 1.07$ & $5.0 \pm 0.49 *$ \\
\hline & $\mathrm{S}_{3}$ & $3.02 \pm 0.12^{c}$ & $9.98 \pm 0.53^{c}$ & $26.28 *$ & $31.16^{*}$ & 42.56 & $452.51 \pm 0.75$ & $9.3 \pm 0.28 * *$ \\
\hline & $\mathrm{S}_{4}$ & $3.53 \pm 0.19^{a}$ & $10.91 \pm 0.44^{b c}$ & 22.14 & 34.09 & 43.77 & $536.32 \pm 0.29$ & $3.5 \pm 0.13^{*}$ \\
\hline & $\mathrm{S}_{5}$ & $3.61 \pm 0.36^{a}$ & $11.76 \pm 0.52^{b}$ & 21.39 & 37.59 & 41.02 & $525.14 \pm 0.13$ & $4.3 \pm 0.16^{*}$ \\
\hline & $\mathrm{S}_{6}$ & $3.45 \pm 0.19^{a b}$ & $11.33 \pm 0.21^{b}$ & $26.52^{*}$ & $27.25^{\star}$ & $46.23^{*}$ & $480.45 \pm 0.32$ & $10.2 \pm 0.44^{\star *}$ \\
\hline
\end{tabular}

Notes: Means with different superscript letter along the column are significantly different $(p<0.05)$ in the SNK test, while means with asterisks are significantly different from control: ${ }^{*} P<0.05$, ${ }^{* *} P<0.001$ according to One-way ANOVA test; NCnegative control (tap water); $\mathrm{S}_{1}$ - $\mathrm{S}_{6}$-lake water samples: $\mathrm{S}_{1}$-Shegan, $\mathrm{S}_{2}$-Dobër, $\mathrm{S}_{3}$-Vrakë, $\mathrm{S}_{4}$-Zogaj, $\mathrm{S}_{5}$-Shirokë, $\mathrm{S}_{6}$-Buna Bridge; MRL-mean root length; MI-mitotic index, PI-phase index; Pr-Prophase; Mt-Metaphase; A/T-Ana/Telophase; INVinterphase nuclear volume; FAC-frequency of aberrant cells; SD-standard deviation. 
Fig. 2. Periodic variation of length, mitotic index, interphase nuclear volume (all expressed as percentage to negative control) and frequency of aberrant cells in A. cepa roots exposed to different Shkodra Lake water samples during 20102013
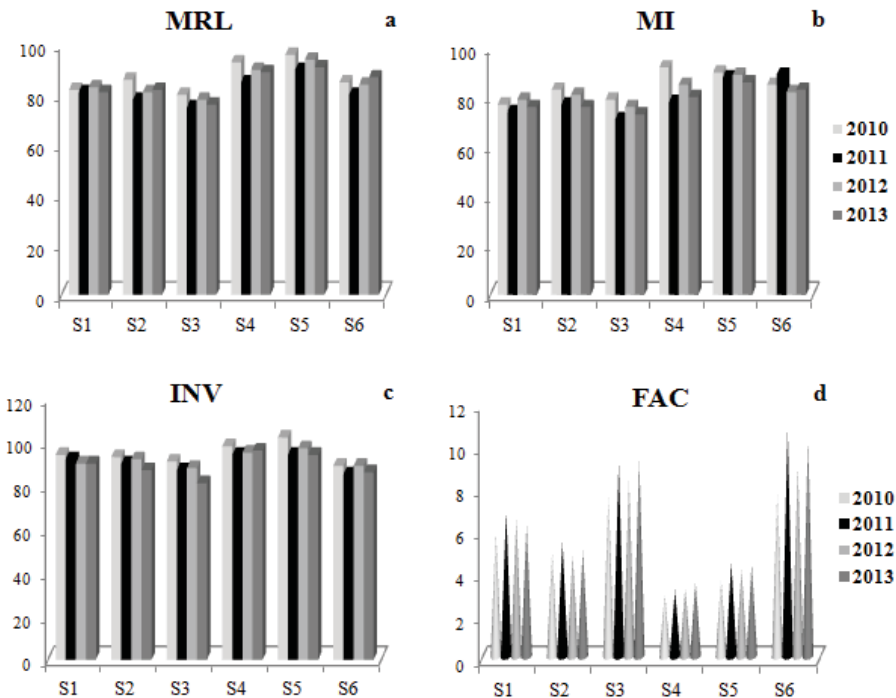

Notes: NC-negative control (tap water); S1-S6 - lake water samples: S1-Shegan, S2-Dobër, S3-Vrakë, S4-Zogaj, S5Shirokë, S6-Buna Bridge; MRL-mean root length; MI-mitotic index; INV-interphase nuclear volume; FAC-frequency of aberrant cells.

\section{References}

Albering, H. J., van Leusen,, S. M., Moonen, E. J. C., Hoogewerff, J. A., \& Kleinjans, J. C. S. (1999). Human health risk assessment: A case study involving heavy metal soil contamination after the flooding of the river Meuse during the winter of 1993-1994. Environmental Health Perspectives, 107(1), 37-44.

Bushati, N., Neziri, A., Bushati, F., \& Hysko, M. (2012). Physical-Chemical and Microbiological Data on Shkodra-Drini-Buna waters (Albania). Journal of International Environmental Application \& Science, 7(2), 391-395.

de Zwart, D. (Ed.) (1995). Monitoring water quality in the future. Biomonitoring (Vol. 3). Bilthoven, Netherlands: RIVM.

Dhora, Dh. (2012). Liqeni i Shkodrës. Shkodër, Albania: Camaj-Pipa.

Düsman, E., Gonçalves, L. A., Reusing, A., Martin, P. G., Mariucci, R. G. \& Vicentini, V. E. P., (2012). Cytotoxic potential of waters of the streams Mandacaru, Maringá, Miosótis and Nazareth in the urban area of Maringá, Paraná State. Acta Scientiarum. Biological Sciences, 34(3), 311-318.

Fiskesjö, G. (1988). The Allium test-an alternative in environmental studies: the relative toxicity of metal ions. Mutation Research, 197, 243-260.

Kopliku, D., Mesi, A. \& Golemi, S. (2012) Citotoxicity and genotoxicity screening of some aquatic bodies in Shkodra region using Allium cepa L. test. Mediterranean Journal of Social Sciences 3(5), 271-276.

Kopliku, D. \& Mesi, A. (2013). Assessment of cytotoxic and genotoxic potency of $\mathrm{Cr}(\mathrm{VI})$-doped river water of Nën-Shkodra lowland, Albania, on Allium cepa L. Journal of Environmental Research and Development, 7(4), 1322-1332.

Leme, D. M., \& Marin-Morales, M. A. (2009). Allium cepa test in environmental monitoring: a review on its application. Mutation Research, 682, 71-81.

Malollari, I., Bacu, A., Bekteshi, A., Babani, F., \& Uku, S. (2012). Nutrition Factors of the Shkodra Lake Waters and Their Distribution. J. of Environmental Protection and Ecology, 13 (2), 532-540.

Matsumoto, S. T.; Mantovani, M. S.; Malagutti, M. I. A.; Dias, A. L.; Fonseca, I. C. \& Marin-morales, M. A. (2006). Genotoxicity and mutagenicity of water contaminated with tannery effluents, as evaluated by the micronucleus test and comet assay using the fish Oreochromis niloticus and chromosome aberrations in onion root tips. Genetics and Molecular Biology, 29(1), 148-158.

Mesi, A. \& Kopliku, D. (2011). Allium test of root growth for toxicity assessment as a standard in environmental monitoring of some aqueous sources of Malësia e Madhe. Journal of International Environmental Application \& Science, 6(5), 654-660.

Mesi, A. Kopliku, D. Neziri, A. \& Golemi, S. (2013). Correlative evaluation between nickel ion concentrations doped in some riverside water bodies of Nën-Shkodra Lowland and root growth of Allium cepa (L.). Asian Journal of Chemistry, 25(5), 2687-2689.

Neziri, A., Lazo, P., Brümmer, J., \& Falcon, R. (2009). Investigation of heavy metal pollution in Shkodra Lake using the inorganic version 
of the Chemcatcher® passive sampler; 3rd International Passive Sampling Workshop and Symposium, Prague, Czech Republic. Power E. A. \& Boumphrey R. S. (2004). International Trends in Bioassay Use for Effluent Management. Ecotoxicology, 13(5), 377-398, Rakaj, M. (2012). Biological Conditions of the Lake Shkodra and the Buna River. Journal of Environmental Protection and Ecology, 13(3), 1397-1404.

Ramsar (2010). The list of wetlands of international importance. [Online] Available:

http://www.ramsar.org/pdf/sitelist.pdf (July 7, 2012)

Siddiqui, A. H. \& Ahmad, Sh. M. (2011). Validation of plant based bioassays for the toxicity testing of Indian waters. Environmental Monitoring and Assessment, 179, 241-253.

Smaka-Kincl V., Stegnar P., Lovaka M. \& Toman J. (1996). The evaluation of waste, surface and ground water quality using the Allium test procedure. Mutation Research, 368, 171-179.

Vargas, V. M. F., Migliavacca, S. B., de Melo, A. C., Horn, R. C., Guidobono, R. R., Ferreira, I. \& Pestana, M. H. D. (2001). Genotoxicity assessment in aquatic environments under the influence of heavy metals and organic contaminants. Mutation Research Genetic Toxicology and Environmental Mutagenesis, 490, 141-58.

Žegura, B., Heath, E., Černoša, A., \& Filipič, M. (2009). Combination of in vitro bioassays for the determination of cytotoxic and genotoxic potential of wastewater, surface water and drinking water samples. Chemosphere,75, 1453-60. 